\title{
The Development of Gluten-Eggs Free Cookies as Functional Food
}

\author{
Mutiara Nugraheni ${ }^{1}$, Sutopo ${ }^{2}$, Sutriyati Purwanti ${ }^{1}$, Titin Hera Widi Handayani ${ }^{1}$ \\ Culinary Art Education Department ${ }^{1}$ \\ Mechanical Engineering Education Department ${ }^{2}$ \\ Yogyakarta State University \\ Yogyakarta, Indonesia \\ mutiara_nugraheni@uny.ac.id
}

\begin{abstract}
This research aims to develop gluten-eggs free cookies based native Maranta Arundinaceae flour and Maranta Arundinaceae flour rich in RS3, to analyze the chemical composition, and to know the hedonic of semi trained panelists against cookies as well as in vivo evaluation in diabetes mellitus mice. Self rising gluten-eggs free cookies developed with the formula I, II and III. Chemical composition analysis are moisture, ash, protein, fat, carbohydrates, dietary fiber and resistant starch. In vivo tests using wistar mice and analyzed glucose and lipida profile. The results showed that self rising cookies formula $I$ is the most like types of cookies by the panelists. The chemical composition of selected cookies (Formula I): moisture: $4.02 \pm 0.66 \%$, ash content $5.16 \pm 0.16 \%$, Protein: $0.31 \pm$ at $14 \%$, fat cotent $32.56 \pm \mathbf{0 . 0 8 \%}$, dietary fiber: $20.10 \pm$ $0.21 \%$, carbohydrates: $24.78 \pm 0.32 \%$ and resistant starch: $3.50 \pm$ $0.09 \%$. Self rising gluten-eggs free cookies consumption on diabetes mellitus mice can lower glucose and lipida profile. The decrease in glucose profile rate: $45 \%$. The decrease in Total cholesterol, triglycerides and LDL i.e. $30.61 \%, 30.61 \%, 20.35 \%$; and $37.16 \%$. Self rising consumption of gluten-free eggs raise HDL of $126.19 \%$. Based on this research, self rising gluten-eggs free have the potential to be developed as functional foods to prevent and management of diabetes mellitus.
\end{abstract}

Keywords—gluten-egg free, cookies, functional foods

\section{INTRODUCTION}

Indonesia is the country that has the potential for great good natural cereals, legume, or tubers as a source of carbohydrates, fats and proteins. The potential demographic Republic of Indonesia which has a fairly large population i.e. 253.60 million population is ranked the fourth largest population in the world. In addition, according to the WHO, Indonesia has the potential also ranked fourth in the world as people with diabetes mellitus ( 21.3 million) in the year 2030 [1].

Indonesia's potential is great in terms of food sources of carbohydrates and protein that turns out not to make Indonesia have local food-based food security. It is shown by the growing consumption of wheat flour is imported food from year to year. Even within ten years of the national wheat flour could reach 10 million tons per year, then certainly become the largest grain importer in the world [2].

Wheat proteins (gluten) can act as founders of diabetes mellitus type $1[3,4]$. The consumption of gluten free flour mix can provide positive effects on sufferers of type 1 diabetes mellitus [5]. However, the amount of DM type 1 (10-15\%), whereas type 2 DM (85-90\%). So it needs to be an effort in order for the GFF is not only for the management of type 1 $\mathrm{DM}$, but also for type $2 \mathrm{DM}$, by modifying the process on the carbohydrate component. Efforts to develop the GFF is done based on local food sources of carbohydrates, fats, and proteins. The largest constituent component of gluten-free flour mix is carbohydrates, so other than by making use of local potential, then the making of flour has the opportunity to be used for management of diabetes mellitus type 2 by increasing the levels of resistant starch type 3 especially. This is because the resistant starch in a food can have a positive impact, namely improve insulin sensitivity [6]. Some research shows that resistant starch type 3 may improve glucose and lipids profiles on diabetes mellitus mice due to injection of alloxan $[7,8]$. Gluten-free flour mix is able to lower the risk of type 1 diabetes mellitus $[9,10]$. Fiber and resistant starch in foodstuffs being able to control glucose profiles, and animal experiment or human that suffering from diabetes mellitus [11]. Glucose profile control capability is influenced by the glycemic index product. Constituents gluten free flour mix rich in resistant starch type 3 based on local potential is expected to have a low glycemic index.

Resistant starch can be generated from the process of heating and cooling food that contain carbohydrate [12]. The repeated heating and cooling process can increase the levels of resistant starch on carbohiydrate materials [13]. Nugraheni et al. [7], the existence of the processing stages can increase the levels of Coleus tuberosus resistant starch. Nugraheni et al [8] proved that the food source of carbohydrate consumption, i.e. boiled Coleus tuberosus and Coleus tuberosus flake can lower glucose and lipida profile in the diabetes mellitus mice, as well as influencing the formation of SCFA in the colon. One of the tubers as a source of carbohydrates is Maranta Arundinaceae which is the minor tubers that grow in Indonesia

Further research needed for the development of self rising gluten-eggs free cookies that can be accepted by the panelists as well as applied to animals experiment that suffering from diabetes mellitus. The existence of the in vivo studies are expected to provide information about the capabilities of self rising gluten-eggs free cookies rich in resistant starch type 3 for the management of degenerative diseases. i.e. diabetes mellitus at once can encourage the development of local food in order to support the security of the local food sources. So the gluten free flour mix could be developed as a potentialbased functional food premises that are useful in improving public health degrees. 


\section{METHOD}

\section{A. Making of Cookies}

Recipe of cookies referred to Gislen [14]. Gluten-free cookies made from gluten-free flour which is one of the materials constituting Maranta Arundinaceae flour rich in resistant starch type 3 and native Maranta arundinaceae flour. Self rising gluten-eggs free cookies formulations contained in TABLE 1. Difference formulation based on a percentage of the amount of the difference of Maranta arudinaceae flour rich in resistant starch type 3 toward the whole gluten free flour mix.

Making cookies starting with the making of flaxeed gel by adding flaxeed powder as much as 10 grams with $45 \mathrm{ml}$ water, stirred and then allowed in the refrigerator for 15 minutes. On other stage, margarine, sugar, mixed until soft, then added flaxeed gell, mix well then added flour, cocoa powder, cheese and milk essens. The next process is forming the cooking. The next process is the baking with a temperature of the upper and bottom temperature is $120^{\circ} \mathrm{C}$ and $110^{\circ} \mathrm{C}$, during 40 minutes.

\section{B. Hedonic Test}

Hedonik test is carried out on the three formulations self rising gluten free cookies and wheat cookies as a control, use 80 person semi trained panelists. Test hedonik includes color, aroma, flavor, texture and overall. Assessment scale 1 (dislike extremly)-9 (like extremely).

\section{Chemical Analysis Of Cookies}

Chemical analysis include analysis of moisture, protein, fat, ash, carbohydrates and fiber food [15], resistant starch [16].

\section{In Vivo evaluation of Self Rising Gluten-eggs Free Cookies}

Animals experiment are prepared 18 white rats wistar type males weighing 110-150 grams, this consumption test conducted in the laboratory of maintenance of animal experiments Gadjah Mada University. The maintenance in mice with a condition such as uncontrolled light enclosure, ventilation air in the stable condition, the air temperature at room temperature. Standard feed is given for three days by using standard AIN 1993 [17].

The feed standard then made pellet and baking to dry and used as feed rats for 28 days of maintenance. Next up is done weighing weight and intraperitoneal injection of alloxan is done through with a dose of $125 \mathrm{mg} / \mathrm{kg}$ body weight to make the mice being diabetes mellitus. Mice given a feed standard suffering from diabetes. Next up is groups divided. The mice were divided into three groups, namely diet 6 healthy mice with standards feed; 6 diabetes mellitus mice with standard feed and 6 diabetes mellitus mice with self rising gluten-eggs free cookies. Given in drinking water ad libitum. Thee mice feeding is given in every morning. The analysis of blood sugar Glucose method is done by GOD PAP: enzymatic reactions photometric test. Concentrations of cholesterol total, Triglyceride (TG) and low density lipoptotein (LDL) and high density lipoprotein (HDL) are determined by enzymatic colorimetry method using commercial kits.

TABLE I. THE FORMULATION OF CONTROL COOKIES (WHEAT FLOUR) AND THREE TYPES OF GLUTEN-EGGS FREE COOKIES

\begin{tabular}{|c|c|c|c|c|}
\hline \multirow[t]{2}{*}{ Ingredient } & \multicolumn{4}{|c|}{ Types of cookies } \\
\hline & $\begin{array}{c}\text { Wheat } \\
\text { cookies } \\
\text { /Contro } \\
\text { I (g) }\end{array}$ & $\begin{array}{c}\text { Self rising } \\
\text { gluten-eggs } \\
\text { free Cookies } \\
\text { FI 4\% } \\
\text { (g) }\end{array}$ & $\begin{array}{c}\text { Self rising } \\
\text { gluten-eggs } \\
\text { free Cookies } \\
\text { FII 5\% } \\
\text { (g) }\end{array}$ & $\begin{array}{c}\text { Self rising } \\
\text { gluten-eggs } \\
\text { free Cookies } \\
\text { FIII } 6 \%(g)\end{array}$ \\
\hline Wheat flour & 150 & - & - & - \\
\hline $\begin{array}{l}\text { Total Gluten } \\
\text { free flour }\end{array}$ & & 150 & 150 & 150 \\
\hline Ingredient & & & & \\
\hline Shorgum flour & & 67.74 & 62.74 & 62.74 \\
\hline $\begin{array}{l}\text { Rice brand } \\
\text { flour }\end{array}$ & & 57.92 & 57.92 & 57.92 \\
\hline Tapioca flour & & 4.83 & 2.90 & 0.97 \\
\hline $\begin{array}{l}\text { Coleus } \\
\text { tuberosus flour } \\
\text { rich in RS3 }\end{array}$ & & 0.97 & 0.97 & 0.97 \\
\hline $\begin{array}{l}\text { Maranta } \\
\text { arundinaceae } \\
\text { flour rich in } \\
\text { RS3 }\end{array}$ & & 5.79 & 7.72 & 9.65 \\
\hline $\begin{array}{l}\text { Maranta } \\
\text { arundinaceae } \\
\text { flour }\end{array}$ & & 7.72 & 7.72 & 7.72 \\
\hline Guar Gum & & 3.09 & 3.09 & 3.09 \\
\hline Baking Powder & & 6.18 & 6.18 & 6.18 \\
\hline Salt & & 0.77 & 0.77 & 0.77 \\
\hline Flaxseed & & 10 & 10 & 10 \\
\hline Corn syrup & & 15 & 15 & 15 \\
\hline Salt & & 2 & 2 & 2 \\
\hline Chedar cheese & & 75 & 75 & 75 \\
\hline $\begin{array}{l}\text { Chocolate } \\
\text { powder }\end{array}$ & & 5 & 5 & 5 \\
\hline Water & & 45 & 45 & 45 \\
\hline Milk essens & & 10 & 10 & 10 \\
\hline
\end{tabular}

\section{E. Statistical Analysis}

Statistical analysis was analyzed with SPSS version 11.0 (Illinois, USA) using the ANOVA of one line. Different test was done using least significant different.

\section{RESUlt AND DiscuSSION}

\section{A. The Chemical Composition Of Four Types Of Cookies- Based Gluten-Free Flour}

Wheat cookies (as control) and three types of formulations of Cookies that have been created are then analyzed chemical composition that includes the contents of moisture, ash, protein, fat, carbohydrates, resistant starch, and dietary fiber. The chemical composition is contained in Table II.

Based on Table II indicates that each of the three types of formulations cookies have ash levels higher than wheat cookies (as control). Protein levels in three formulations of cookies made lower than wheat cookies ( as control). Wheat cookies (as control) in fat levels lower than the three types of 
formulations of cookies. Three types of formulations cookies contains a high enough dietary fiber $19.75-20.3 \%$. The addition of Maranta Arundinaceae flour rich increases the levels of resistant starch type 3 on cookies. The difference in chemical composition on the cookies that are created are caused by the difference in the composition of the materials constituting.

TABLE II. THE CHEMICAL COMPOSITION OF WHEAT COOKIES (AS CONTROL) AND SELF RISING GLUTEN-EGGS FREE COOKIES

\begin{tabular}{|c|c|c|c|c|c|c|c|}
\hline 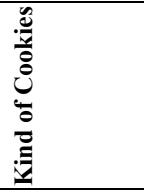 & 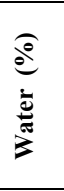 & $\underbrace{e}_{\frac{1}{n}}$ & 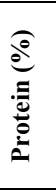 & 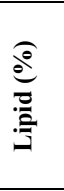 & 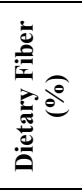 & 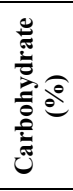 & 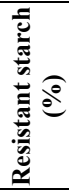 \\
\hline $\begin{array}{l}\text { Wheat } \\
\text { cookies/Co } \\
\text { ntrol }\end{array}$ & $\begin{array}{l}3.88 \\
\pm 0.0 \\
7^{\mathrm{b}} \\
\end{array}$ & $\begin{array}{l}3.45 \\
\pm 0.0 \\
7^{\mathrm{a}} \\
\end{array}$ & $\begin{array}{l}15.1 \\
4 \pm 0 . \\
05^{\mathrm{d}}\end{array}$ & $\begin{array}{l}31.1 \\
4 \pm 0 \\
13^{\mathrm{a}} \\
\end{array}$ & $\begin{array}{l}21.10 \\
\pm 0.13 \\
\mathrm{~d}\end{array}$ & $\begin{array}{l}25.2 \\
1 \pm 0 . \\
11^{\mathrm{b}} \\
\end{array}$ & $\begin{array}{l}2.18 \\
\pm 0.0 \\
8^{\mathrm{a}} \\
\end{array}$ \\
\hline $\begin{array}{l}\text { Self rising } \\
\text { gluten-eggs } \\
\text { free } \\
\text { cookies (F } \\
\text { I) }\end{array}$ & $\begin{array}{l}4.02 \\
\pm 0.6 \\
6^{c}\end{array}$ & $\begin{array}{l}5.16 \\
\pm 0.1 \\
6^{\mathrm{b}}\end{array}$ & $\begin{array}{l}14.0 \\
2 \pm 0 . \\
31^{\mathrm{c}}\end{array}$ & $\begin{array}{l}32.5 \\
6 \pm 0 . \\
08^{c}\end{array}$ & $\begin{array}{l}20.10 \\
\pm 0.21 \\
\mathrm{~b}\end{array}$ & $\begin{array}{l}24.7 \\
8 \pm 0 . \\
32^{\mathrm{a}}\end{array}$ & $\begin{array}{l}3.50 \\
\pm 0.0 \\
9^{b}\end{array}$ \\
\hline $\begin{array}{l}\text { Self rising } \\
\text { gluten-eggs } \\
\text { free } \\
\text { cookies (F } \\
\text { II) }\end{array}$ & $\begin{array}{l}4.32 \\
\pm 0.1 \\
0^{\mathrm{d}}\end{array}$ & $\begin{array}{l}5.21 \\
\pm 0.1 \\
0^{\mathrm{c}}\end{array}$ & $\begin{array}{l}11.4 \\
5 \pm 0 . \\
03^{\mathrm{a}}\end{array}$ & $\begin{array}{l}32.3 \\
7 \pm 0 \\
11^{\mathrm{b}}\end{array}$ & $\begin{array}{l}19.75 \\
\pm 0.13^{\mathrm{a}}\end{array}$ & $\begin{array}{l}26.5 \\
6 \pm 0 . \\
13^{\mathrm{d}}\end{array}$ & $\begin{array}{l}3.67 \\
\pm 0.1 \\
1^{\mathrm{c}}\end{array}$ \\
\hline $\begin{array}{l}\text { Self rising } \\
\text { gluten-eggs } \\
\text { free } \\
\text { cookies (F } \\
\text { III) }\end{array}$ & $\begin{array}{l}3.4 \pm \\
0.66 \\
a\end{array}$ & $\begin{array}{l}5.73 \\
\pm 0.1 \\
9^{\mathrm{d}}\end{array}$ & $\begin{array}{l}12.6 \\
1 \pm 0 . \\
06^{\mathrm{b}}\end{array}$ & $\begin{array}{l}32.3 \\
8 \pm 0 . \\
10^{\mathrm{b}}\end{array}$ & $\begin{array}{l}20.33 \\
\pm 0.18^{\mathrm{c}}\end{array}$ & $\begin{array}{l}25.5 \\
8 \pm 0 . \\
15^{\mathrm{c}}\end{array}$ & $\begin{array}{l}4.27 \\
\pm 0.1 \\
9^{d}\end{array}$ \\
\hline
\end{tabular}

The numbers are averages $\pm \mathrm{SD}$; the difference of the letters (a-d) on the same row showed significant differences $(\mathrm{P} 0.05<)$

\section{B. Hedonik Test of Self Rising Gluten-Eggs Free Cookies}

Hedonik Test done to find out the types of cookies that are most favored by panelists. To then further developed in the evaluation of in vivo on animals try suffering from diabetes mellitus. Panelists used are semi trained panelists, that panelists who already have knowledge and experience to assessing a product with a sensory testing principles. The number of panelists used is 80 people.

Sensory characteristics of cookies being evaluated are the aroma, color, flavor, texture and overall acceptability (TABLE III). Self rising gluten-eggs free cookies has favored acceptance rate. However, compared to control, namely wheat cookies, then cookies are made with three formulations i.e. $4 \%, 5 \%$ and $6 \%$ have lower numbers of hedonic test. Cookies gluten free flour-based formula I $(4 \%)$ had the highest acceptance compare thanthe formula II $(5 \%)$ and formula III $(6 \%)$. So the cookies with the formula I $(4 \%)$ is to be used for animal diets try suffering from diabetes mellitus.

TABLE III. SENSORY CHARACTERISTICS OF WHEAT COOKIES (AS CONTROL) AND SELF RISING GLUTEN-EGGS FREE COOKIES

\begin{tabular}{|c|c|c|c|c|}
\hline \multirow[t]{2}{*}{ Characteristics } & \multicolumn{4}{|c|}{ Kind of Cookies } \\
\hline & $\begin{array}{c}\text { Wheat } \\
\text { flour } \\
\text { Cookies } \\
\text { (control) }\end{array}$ & $\begin{array}{c}\text { Self rising } \\
\text { (Formula I) }\end{array}$ & $\begin{array}{c}\text { Self rising } \\
\text { (Formula } \\
\text { II) }\end{array}$ & $\begin{array}{c}\text { Self } \\
\text { rising } \\
\text { (Formul } \\
\text { a III) }\end{array}$ \\
\hline Aroma & $\begin{array}{ll}8,01 & \pm \\
0,58^{\mathrm{c}} & \end{array}$ & $\begin{array}{l}7,60 \\
0,52^{\mathrm{b}}\end{array}$ & $\begin{array}{l}7,20 \\
0,62^{\mathrm{a}}\end{array}$ & $\begin{array}{l}7,11 \\
0,76^{\mathrm{a}}\end{array}$ \\
\hline Colour & $\begin{array}{ll}7,93 & \pm \\
0,67^{\mathrm{c}} & \end{array}$ & $\begin{array}{l}7,68 \\
0,62^{\mathrm{b}}\end{array}$ & $\begin{array}{l}7,23 \\
0,62^{\mathrm{a}}\end{array}$ & $\begin{array}{ll}7,06 & \pm \\
0,62^{\mathrm{a}} & \end{array}$ \\
\hline Taste & $\begin{array}{ll}7,89 & \pm \\
0,50^{\mathrm{c}} & \end{array}$ & $\begin{array}{l}7,69 \\
0,61^{\mathrm{b}}\end{array}$ & $\begin{array}{l}7,14 \\
0,61^{\text {a }}\end{array}$ & $\begin{array}{l}7,03 \\
0,68^{\mathrm{a}}\end{array}$ \\
\hline Texture & $\begin{array}{l}7,82 \\
0,55^{\mathrm{b}}\end{array}$ & $\begin{array}{l}7,71 \\
0,53^{\mathrm{c}}\end{array}$ & $\begin{array}{l}7,14 \\
0,61^{\mathrm{a}}\end{array}$ & $\begin{array}{ll}7.05 & \pm \\
0,69^{\mathrm{a}}\end{array}$ \\
\hline $\begin{array}{l}\text { Overall } \\
\text { aceptability }\end{array}$ & $\begin{array}{ll}7,90 & \pm \\
0,54^{\mathrm{c}} & \\
\end{array}$ & $\begin{array}{l}7,70 \\
0,61^{\mathrm{b}}\end{array}$ & $\begin{array}{l}7,21 \\
0,63^{\mathrm{a}} \\
\end{array}$ & $\begin{array}{ll}7,06 & \pm \\
0,68^{\mathrm{a}} & \end{array}$ \\
\hline
\end{tabular}

The numbers are averages $\pm \mathrm{SD}$; the difference of the letters (a-c) on the same row showed significant differences $(\mathrm{P} 0.05<)$

\section{In Vivo Evaluation Of Self Rising Gluten-Eggs Free Cookies On Diabetes Mellitus Mice}

In vivo evaluation of self rising gluten-eggs cookies are done on wistar mice that are injected with alloxan so suffer dabetes mellitus. Consumption evaluation conducted for 28 days after mice suffering diabetes mellitus. In vivo tests carried out on as much as 18 mice that are divided into three groups, namely the group of healthy mice that gets a standard feed diet, groups of diabetes mellitus mice with feed standards diet, and a diabetes mellitus mice with self rising gluten-eggs free cookies diet.

Based on Table IV. indicates that the mice who were given feed in the form of self rising gluten-eggs free cookies gives a positive impact against reduce profile of glucose and lipida profile (total cholesterol, triglycerides, and LDL).

TABLE IV. PROFILE OF GLUCOSE AND LIPIDS ON WISTAR MICE FEED WITH STANDARD FEED AND SELF-RISING GLUTEN-EGGS FREE COOKIES

\begin{tabular}{|c|c|c|c|c|c|c|}
\hline \multirow[t]{2}{*}{ Parameter } & \multicolumn{2}{|c|}{ Healthy mice with standard feed } & \multicolumn{2}{|c|}{ Diabetic mice with standard feed } & \multicolumn{2}{|c|}{$\begin{array}{c}\text { Diabetic mice with self rising } \\
\text { gluten-eggs free cookies }\end{array}$} \\
\hline & 0 days & 28 days & 0 days & 28 days & 0 day & 28 days \\
\hline Glucose (mg/dl) & $70.00 \pm 2.0^{\mathrm{b}}$ & $68.67 \pm 2.34^{\mathrm{a}}$ & $220.67 \pm 6.98^{\mathrm{e}}$ & $223.33 \pm 2.86^{\mathrm{f}}$ & $211.00 \pm 4.28^{\mathrm{d}}$ & $116.00 \pm 1.67^{\mathrm{c}}$ \\
\hline $\begin{array}{ll}\begin{array}{l}\text { Cholesterol } \\
(\mathrm{mg} / \mathrm{dl})\end{array} & \text { Total } \\
\end{array}$ & $79.17 \pm 2.04^{\mathrm{a}}$ & $82.00 \pm 2.28^{b}$ & $183.83 \pm 3.87^{\mathrm{e}}$ & $188.83 \pm 5.85^{\mathrm{f}}$ & $181.33 \pm 3.4^{\mathrm{c}}$ & $125.83 \pm 3.97^{\mathrm{d}}$ \\
\hline Triglycerides $(\mathrm{mg} / \mathrm{dl})$ & $69.00 \pm 1.41^{\mathrm{a}}$ & $74.17 \pm 2.56^{\mathrm{b}}$ & $128.67 \pm 2.50^{\mathrm{e}}$ & $137.83 \pm 7.41^{\mathrm{f}}$ & $125.33 \pm 2.94^{\mathrm{d}}$ & $99.83 \pm 1.72^{\mathrm{c}}$ \\
\hline LDL (mg/dl) & $26.33 \pm 2.07^{\mathrm{a}}$ & $30.50 \pm 2.59^{b}$ & $75.67 \pm 1.37^{\mathrm{e}}$ & $80.67 \pm 2.42^{f}$ & $74.00 \pm 1.41^{\mathrm{d}}$ & $46.50 \pm 2.43^{\mathrm{c}}$ \\
\hline $\operatorname{HDL}(\mathrm{mg} / \mathrm{dl})$ & $68.83 \pm 2.14^{\mathrm{f}}$ & $64.17 \pm 1.94^{\mathrm{e}}$ & $25.17 \pm 1.47^{\mathrm{c}}$ & $22.00 \pm 2.37^{\mathrm{a}}$ & $24.17 \pm 2.56^{\mathrm{b}}$ & $54.67 \pm 2.73^{\mathrm{d}}$ \\
\hline
\end{tabular}


A positive impact against glucose on self rising gluteneggs free cookies suspected of being caused by content of dietary fiber and resistant starch contained in flour are used. The mice suffering from diabetes after feeding standard feed and self rising gluten-eggs free cookies shows a decrease in serum glucose levels are significant and leads to normal serum glucose levels after treatment for 28 days. Based on the analysis of the statistics can be known that there is a significant difference between the mice suffering from diabetes mellitus who were given standard feed diet and self rising gluten-eggs free cookies. Diabetic mice fed a standard diet did not experience a decrease in serum glucose levels. The decrease in serum glucose in self rising gluten-eggs free cookies is $45 \%$. Standard feed does not occur on a decrease in serum glucose. This data shows that the types of starch in conjunction with resistant starch, dietary food fiber levels and potentially to lower serum glucose than standard fodder.

According to Cumming [18], resistant starch is starch that resistant on digestion by the digestion enzyme on healthy individuals. Due to the resistant starch then the glucose produced too little, so that accounts for the low response of postprandial for foods containing high amylose or included in resistant starch. Resistant starch has been reported are also hipoglycemic. RS lower glycemic response due to its viscous fiber in food as well as water soluble so it inhibits the absorption of glucose.

Sajilata et.al [19] States that foods containing RS will be slow digestion, this gives implications for controlling the release of glucose. Metabolism of RS occurred 5-7 hours after consuming, and this contrasts with the cooked starch (which is not included in the RS) can be digest immediately. The digestion 5-7 hour will reduce postprandial glycemia and insulemia. The research indicates that resistant starch and dietary fiber is capable of lowering glucose levels significantly, so that self rising gluten-eggs free cookies can be used as raw material for the production of foods that have a purpose for glucose profile management.

Diabetes has an impact on the metabolism of lipids, where one of the impact of diabetes disease is the occurrence of elevated levels of both lipids profile: total cholesterol, triglycerides, and LDL. On this research using diabetes mellitus mice diet fed on feed standards, or self rising gluteneggs free cookies. After being given a diet self rising gluteneggs free cookies until 28 days indicated that cholesterol total, triglycerides and LDL showed a noticeable decline compared to mice of diabetes mellitus (control) with standard feed diet.

Based on TABLE 4. The rats suffering from diabetes after feeding standard feed and self rising gluten-eggs free cookies shows the total cholesterol levels decrease amounted to $30.61 \%$. On a standard feed increase total cholesterol $2.7 \%$.

The mice suffering from diabetes after feeding good standard and feed gluten free self rising shows triglyceride levels decrease significantly. Based on the analysis of the statistics can be known that there is a significant difference between diabetes mellitus rats who were given standard feed diet with self rising gluten-egg free cookies. Mice fed a standard diet did not experience a decrease in serum triglyceride levels, whereas a decrease occurred in the diet of four types of cookies are gluten-free and egg-free. Decrease in triglycerides in Group feed cookies gluten free self rising $20.35 \%$. On a standard feed increase triglycerides $0.7 \%$.

The mice suffering from diabetes mellitus after feeding standard feed, self rising gluten-eggd free cookies showed decreased levels of LDL. Based on the analysis of the statistics can be known that there is a significant difference between diabetes mellitus mice fed a standard diet and self rising gluten-eggs free cookies. Decrease LDL on the group self rising gluten-eggs free cookies is $37.16 \%$. On a standard feed increase LDL $6.61 \%$.

The decrease lipids profile relates to the existence of resistant starch. The mechanism of resistant starch in lower profile lipids are binding bile acids and increases the excretion of bile acids via the stool so that the amount of bile acids that are used less. To compensate excretion bile acids, liver syntezid bile acids recently and this reduces cholesterol serum levels. RS replace the pool of bile acids from cholic acid becomes chenodeoxycholic acid is an inhibitor of an enzyme required for the biosynthesis of cholesterol. The activity of HMG CoA reductase is low in production of cholesterol will decrease, and it causes cholesterol serum is down.

Damat et.al [20] that the RS binds bile acids, increases the viscosity of the contents of the intestine so as inhibit absorbs various types of macro-nutrient, including lipids and reduction of absornsi bile acids from the intestine through the circulation of enterohepatic. It causes a decrease in cholesterol total, accompanied by a decrease in the concentration of LDL. Han et.al [21], feed containing RS increasing mRNA hepatic cholesterol 7a-hydroxylase and increasing steroid and bile acid that excretion in feces.

The levels of HDL blood should preferably be above 60 $\mathrm{mg} / \mathrm{dL}$. When the levels of HDL below $40 \mathrm{mg} / \mathrm{dL}$, then it can trigger the onset of heart disease. The rats suffering from diabetes after feeding a standard feed, and self rising gluteneggs free cookies showed increased levels of HDL significantly. Based on the analysis of the statistics can be known that there is a significant difference between mice with standard feed and self rising gluten-eggs free cookies. The increase of HDL on the group feed with self rising gluten-eggs free cookies rising $126.19 \%$. On a standard feed decrease HDL $0.12 \%$. Polysaccharides and dietary fiber that viscous food may inhibit the rate of absorption of glucose and sterol in the intestine. The nature of the layer thickness viscous believed to raise between the food and the surface of the brush-border in the intestine thus preventing absorbs nutrients.

Diet self rising gluten-eggs free cookies influenced against profiles of glucose and lipids in mice suffering from diabetes mellitus showed a positive impact. It can be known from the trend of parameters of glucose levels, cholesterol total, triglyceride (TG) and LDL that shows declining trend and approaching normal levels in rats. While the HDL parameter indicates an increase approaching normal HDL levels. Profile improvement of glucose and lipids profile in diabetes mice relating to functional properties of self rising gluten-eggs free cookies that contain resistant starch and dietary fiber. 


\section{CONCLUSION}

Self rising gluten-eggs free cookies contain resistant starch and dietary fiber. Self rising gluten-eggs free cookies formula I is cookes that gets the favorable response and in the category of preferred compared with Formula II and III. The influence of consumption of formula I cookies give a positive impact against the profile of glucose and lipida animals experiment diabetes mellitus. So the gluten free flour-based cookies has a potential as a functional food.

\section{ACKNOWLEDGEMENT}

The authors would like to thank the Direcorate General of Higher education of The Republic of Indonesia, for research grant wuth contract number: 04/P. Stranas/UN34.21/2017, 3 April 2017.

\section{REFERENCE}

[1] S. Wild, G. Roglic, A. Green, R. Sicree, H. King. Global Prevalence of Diabetes Estimates for the year 2000 and projections for 2030. Diabetes care Journal 27(5): 1047-1053 (2004).

[2] A.R. Yanuarti, M.D. Afsari. Profile of commodity goods, basic necessities and goods important commodities wheat. Ministry of Trade Republic of Indonesia (2016).

[3] S. Hogg-Kollars, D.A. Dulaimi, K. Tait, K Rostami, Gastroenterol Hepatol Bed Bench 7(4), 189- 197 (2014).

[4] K. Filbert, S.S. Sein, CDK201.Vol 40(2): 102-106 (2013).

[5] C. Kupper, L.A. Higgins, 2007. The Celiac, series 7. Practical gastroenterology (2007).
[6] M.D. Robertson, A.S. Bickerton, A.L. Dennis, H. Vidal, K.N. Frayn, Am J Clin Nutr 82, 559-67 (2005).

[7] M. Nugraheni, U. Santoso, Windarwati., 2010. Strategic National Research Progress (2010).

[8] M. Nugraheni, U. Santoso, Windarwati, 2012. Volume 18 Issue 4 (2002).

[9] F.L. Soares, R.O. Matoso, L.G. Teixeira, Z. Menezes, S.S. Pereira, A.C. Alves, N.V. Batista, A.M.C. Faria, D.C. Cara, A.V.M. Ferreira, J.I Alvarez-Leite., J Nutr Biochem24(6):1105-11 (2012).

[10] C.R. Parrish, The Celliac diet. Combining Diabetes and Gluten-Free Dietary Management Guidelines (2013).

[11] M. Nugraheni, Windarwati, S. Hamidah, 2014. Adv J Food Sci Technol. 6(2): 159-166 (2014).

[12] S.M. Kingman, H.N. Englyst. Food Chem. 49:181-186 (1994).

[13] A.N. Dundar, D. Gocmen, 2013. Carbohydrate Polymer, 97(2): 764-771 (2013).

[14] W. Gisslen. Professional baking. 6th edition. John Willey and Sons (2012).

[15] AOAC, 18th edn. Association of Offcial analytical Chemists, Gaithersburg, Maryland, USA (2005)

[16] H.N. Englyst, S.M. Kingman, J.H. Cummings, European Journal of Clinical Nutrition 46: S33-S50 (1992).

[17] P.G. Reeves, F.H. Nielsen, G.C. Fahey Jr, 1993. Journal Nutrition, 123: 1939-1951 (1993).

[18] J.H. Cummings, S.A. Bingham, Cancer Surv., 6: 601-621 (1987).

[19] M.G. Sajilata, R.S. Singha, P.R. Kulkarni, Compr Rev Food Sci Food Saf. 5, 1-17 (2005).

[20] D. Damat, J. Food Res., 2: 144-149 (2013).

[21] K.H. Han, M. Iijuka, K.I. Shi, Br. J. Nutr., 94(6): 902-908 (2005). 